\title{
THE SPECIES OF DIAPHEROMERA (PHASMIDAE) FOUND IN THE UNITED STATES AND CANADA.
}

BY SAMUEL H. SCUDDER, CAMBRIDGE, MASS.

The common "walking stick" of the oak bushes of the northern United States, $D$. femorata (Say), was the only species known to Gray, when in 1835 he founded this genus. It was not until $\mathrm{r} 864$ that a second, intimately allied, species was added by Walsh, and since 1875 , when a third much larger species was described by Stål, no further additions have been made. From rather meagre material in my collection I can now add two other species, one from North Carolina, the other from New Mexico. No species appears to occur west of the continental divide. I subjoin a table for the easy separation of the species, based principally on the male sex.

\section{Table of the United States species of Diapheromera.}

$a^{1}$. Male cerci more or less, generally conspicuously, arcuate.

$b^{1}$. Larger and stouter form; under side of middle and hind femora distinctly spined throughout; male cerci much broader apically than at base, more or less spatulate.

- denticrus.

$b^{2}$. Smaller and slenderer forms; middle and hind femora without conspicuous spines beneath, excepting the subapical spine; male cerci subequal throughout.

$c^{1}$. Ninth abdominal segment of male apically inflated, and here nearly half as broad again as at base, the seventh and eighth segments of subequal length

carolina.

$c^{2}$. Ninth abdominal segment of male subequal, scarcely larger at apex than at base, the seventh segment much longer than the eighth.

$d^{1}$. Male cerci with a blunt tooth at inner inferior base; female cerci relatively stout, about half as long as last dorsal segment

femorata.

$d^{2}$. Male cerci with a sharp thorn at inner inferior base; female cerci relatively slender, almost or quite as long as last dorsal segment . . . . . . . . . . . . veliei.

$a^{2}$. Male cerci rigidly straight . . . . . . . mesillana.

\section{Diapheromera denticrus.}

Diapheromera denticrus Stål, Rec. Orth., iii, 76 (1875).
Originally described from Opelousas, La. My specimens all come from Texas (Belfrage), New Braunfels, Tex. (Lincecum), and the Gulf coast of 
Texas (Aaron), excepting a small female from Las Cruces, N. Mex. (Cockerell). It is perhaps this species to which Gosse alludes (Lett. Alab., 275) as the larger of two species found in Alabama. It varies somewhat in size, two males before me being respectively 90 and $125 \mathrm{~mm}$. in length. The species is figured of half natural length in Harper's Magazine, vol. lxxxviii, p. 457.

\section{Diapheromera carolina sp. nov.}

J. Stouter than D. femorata, testaceocastaneous, glistening, the thorax with a rather broad median bronze-fuscous stripe, not reaching the median segment, and interrupted at the posterior end of the mesonotum, the fore legs greenish, the antennae testaceous; thorax with excessively fine transverse striation. Mesothorax and metathorax (including median segment) of similar length. Seventh and eighth abdominal segments of subequal length, each faintly enlarging from base, the ninth a little shorter, apically inflated and subglobose, nearly half as broad again at apex as at base, the cerci much as in $D$. femorata, but stouter, more compressed and without basal tooth.

Length of body, $67 \mathrm{~mm}$.; head, $3 \mathrm{~mm}$.; mesuthorax, $13.5 \mathrm{~mm}$; fore femora, 20.5 $\mathrm{mm}$.; middle femora, $\mathrm{I} 4.5 \mathrm{~mm}$; hind femora, $19.5 \mathrm{~mm}$.

I d. North Carolina (Morrison).

In most features this species stands nearly intermediate between $D$. denticrus and D. femorata.

\section{Diapheromera femorata.}

Spectrum femoratum Say, Exp. Long, ii, 297 (1824); Amer. ent., iii, pl. 37 (1828).
Diapheromera femorata Harr., Treat. ins. inj. veg., I I9 (1840, r84r).

Phasma (Bacteria) femorata de Haan, Bijdr. kenn. Orth., IOI, I34 (1842).

Bacunculus femoratus Uhl., Harr., Treat. ins. inj. veg., 3 ed., I46 (1862).

Diapheromera sayi Gray, Syn. Phasm., 18 (1835).

Bacteria sayi Charp., Orth. descr., pl. $6($ I 84 I-1 845$)$.

Bacteria (Bacunculus) sayi Burm., Handb. ent., ii, 566 (1838).

Bacunculus sayi Thom., Trans. Ill. st. agric. soc., v, 44I (1865).

Bacteria linearis Gosse, Lett. Alab., 275 (1859).

Originally described from the "United States," Niagara and the Missouri River being specified. I have seen specimens from Prout's Neck, Me., Vermont, vic. Boston, Massachusetts, Prescott, Ont. (Billings), New York, Niagara Falls, Maryland (Uhler), Virginia, Illinois, Manitoba, Jefferson, Dallas Co. and Denison, Iowa (Allen), St. Louis, Mo., Dallas, Tex. (Boll) and Ringgold Barracks, Tex, (Schott). It has also been reported, but perhaps sometimes by mistake for the next species, from Montreal (Caulfield), New Hampshire (Scudder), New Jersey (Say, Smith), Pennsylvania (de Haan), Wisconsin (Walsh and Riley), Minnesota (Lugger), Kansas and $\mathrm{Ne}$ braska (Bruner), Kentucky (Garman), Indiana (Blatchley), South Carolina (de Haan), Tennessee (de Haan, Saussure), Alabama (Gosse), New Mexico and Mexico (Haldeman). 
The species has been frequently figured.

\section{Diapheromera veliei.}

Diapheromera velii Walsh, Proc. ent. soc. Philad., iii, 409-410 (1864).

Originally described from Nebraska, and since then reported only from that state and Illinois. I have seen specimens from Maryland (Uhler), Virginia Wirt Robinson), Georgia (Morrison), Ohio, Southern Illinois (Thomas), Manitoba, Dallas Co. and Jefferson, Iowa (Allen), Lincoln, Valentine and Sand Hills, Nebr. (Bruner), Platte River, Nebr. (Hayden), Barber Co., Kans. (Bruner), Dallas, Tex. (Boll), Ringgold Barracks, Tex. (Schott), Pecos River (Capt. Pope), Albuquerque, N. Mex. (Bruner), Sancelito, Mex. (Palmer), San Pedro and Montelovez, Coahuila, Mex. (Palmer), and Venis Mecas and Sierra San Miguelito, San Luis Potosi, Mex. (Palmer).
Diapheromera mesillana sp. nov.

J. Slenderer than D. femorata, uniform greenish flavous, the antennae infuscated beyond the basal third, the thorax smooth, with an obscure median carina; subapical inferior spine of middle and hind femora rather slight. Mesothorax and metathorax (including median segment) of equal length. Seventh and ninth abdominal segments subequal in length and distinctly longer than the eighth, all equal in width and nowhere enlarged, the ninth rather feebly and angularly emarginate, exposing a small, transverse, apically arcuate, supraanal plate; cerci about as long as the ninth abdominal segment, rigidly straight, directed backward and not at all downward, slender, tapering, blunt tipped, externally convex, and internally concave.

Length of body, $55 \mathrm{~mm}$; head, $3 \mathrm{~mm}$; antennae, circa $37 \mathrm{~mm}$; mesothorax, 12.5 $\mathrm{mm}$.; fore femora, $\mathrm{I} 4.5 \mathrm{~mm}$.; middle femora, I $\mathrm{mm}$.; hind femora, $13.5 \mathrm{~mm}$.

$2 \pi$. Between Mesilla and Las Cruces, N. Mex., June 30 (A. P. Morse).

\section{LIFE HISTORIES OF NORTH AMERICAN GEOMETRIDAE. - XXI.}

BY HARRISON G. DYAR, WASHINGTON, D. C.

Eudule mendica Walk. This larva has proved unusually difficult and for no real reason. As early as $187 \mathrm{I} \mathrm{Mr}$. W. Saunders published on the first stage, but was unable to go further as he could find nothing that the larvae would eat. I have tried the same experiment with equal ill success, till the fortunate discovery of the food plant by Mr. Lucock (Can. ent., xxx, 248, 1898) rendered the whole matter simple. The food plant was also independently discovered by
Mr. W. D. Kearfott, who has kindly presented to me an inflated larva and pupa shells.

The first stage has been described by Saunders, the last by Lucock, both briefly and the pupa has been remarked on by Hulst and Smith.

Egg. Suspended on a slender silken fibre which runs from one object to another so that the egg swings free in the air. In nature the eggs were found laid on sheep's 

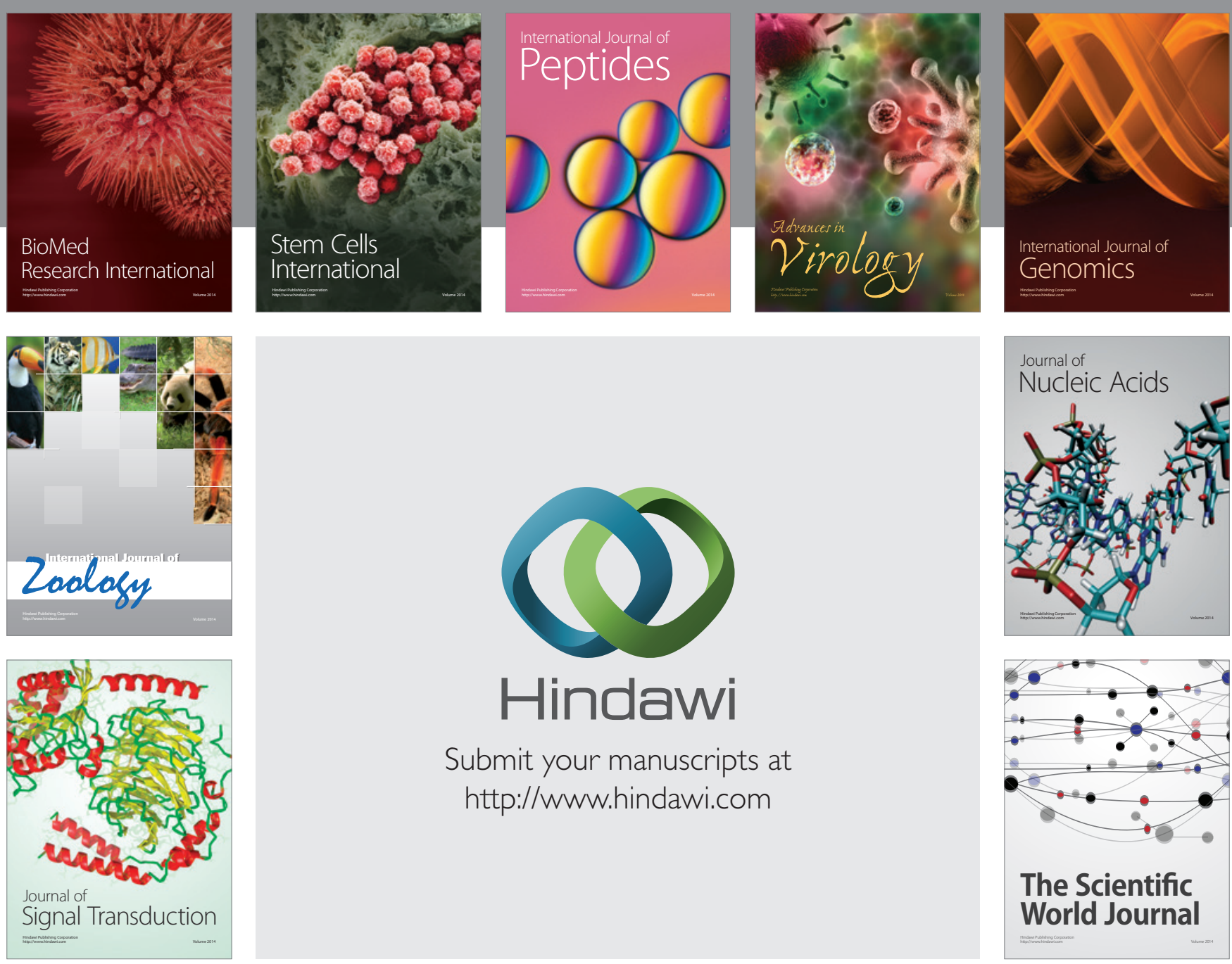

Submit your manuscripts at

http://www.hindawi.com
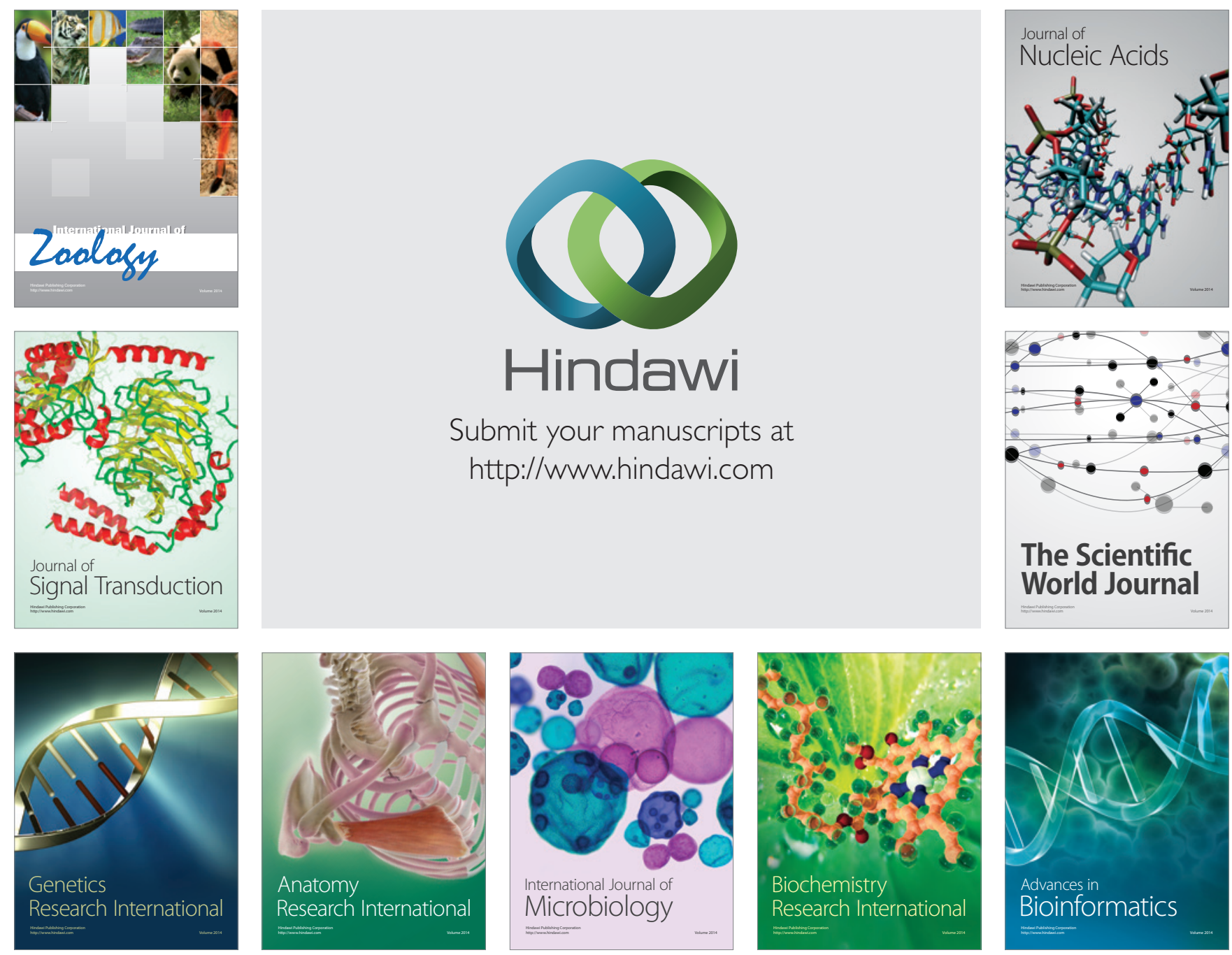

The Scientific World Journal
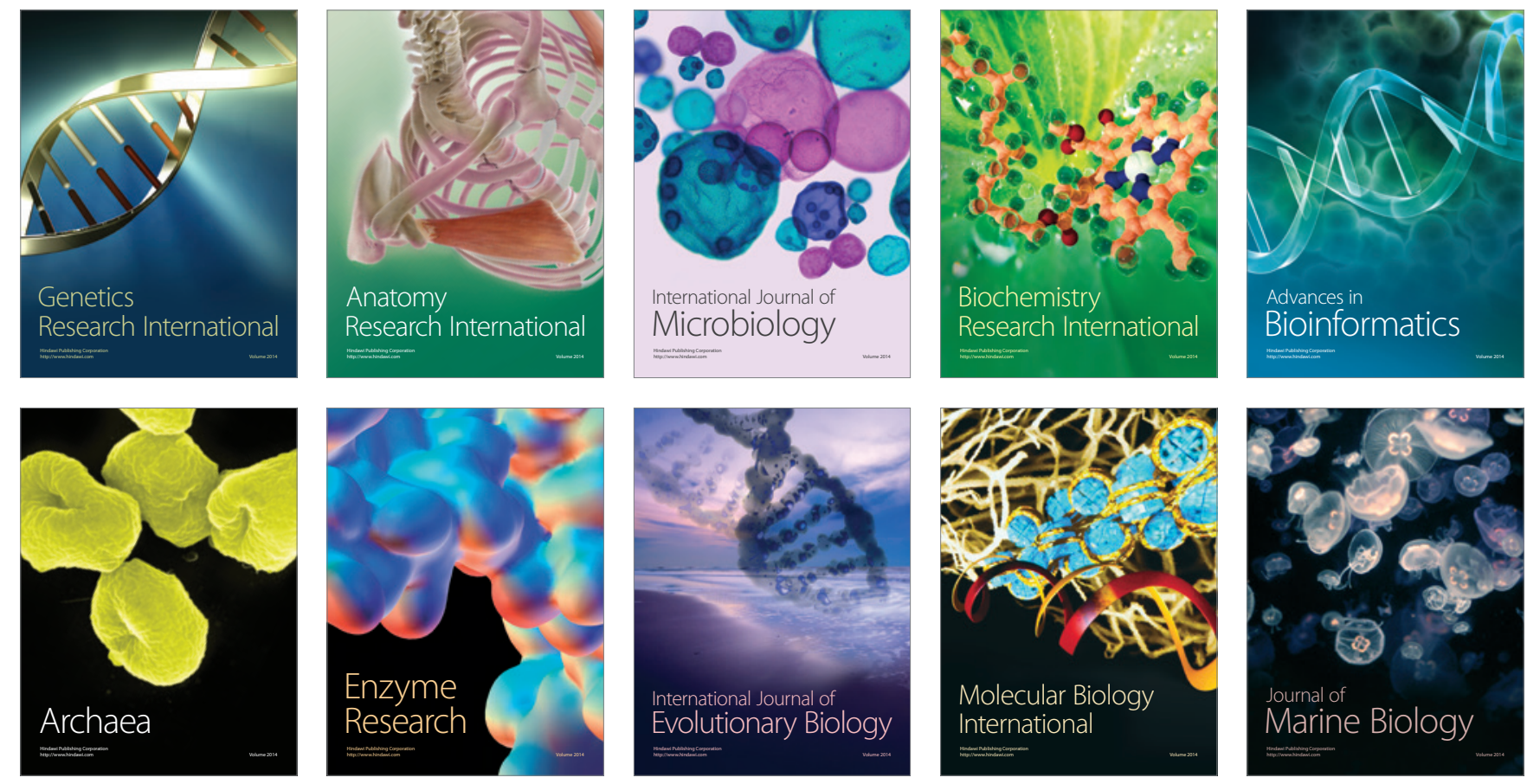